\title{
Framing the field of popular music history and heritage studies
}

Zelmarie Cantillon, Catherine Strong, Lauren Istvandity and Sarah Baker

At the end of 2016, the Victorian State Government in Australia announced the establishment of the Australian Music Vault, 'a new exhibition space dedicated to sharing the story of Australian contemporary music' (Creative Victoria 2016). The idea of an Australian popular music museum or hall of fame had been discussed for a long time, but the Victorian government's desire to establish the state as the cultural leader in Australia, and to position Melbourne as a global 'music city' provided the impetus for funding actually being committed to this heritage project. A number of 'patrons' who were contributing to the funding for the institution were also announced, comprising long-time players in the Australian music industry such as Ian 'Molly' Meldrum (music journalist and Australian icon), Michael Gudinski (owner of Australia's most successful independent record label Mushroom) and musicians Archie Roach and Kylie Minogue. Currently, the curators are working with pre-existing popular music-related collections in Australian cultural institutions, but are also starting to collect additional resources, inviting the public to contact them with information about further possible acquisitions (Dwyer 2017).

The establishment of the Vault speaks to many of the key themes in this volume, as well as demonstrating why such a volume is necessary at this point in time. Australia is not breaking any new ground in creating this institution; if anything, the country has been slow to respond to the growing international trend of incorporating popular music into national discourses of history and heritage. The Vault comes, however, at a time when activities reflecting such a shift in Australia have been increasing; over the last decade scholarship on popular music heritage in Australia has covered a range of activities including the 2014 Melbourne, Music and Me exhibition focusing on Mushroom Records (Breen 2016); the naming of streets in the Melbourne CBD after musicians (Strong 2015, Strong, Cannizzo, and Rogers 2017); television series on the history of Australian popular music (Homan 2017); and the memorialisation of country music's past in Tamworth, Australia's self-proclaimed 'Country Music Capital' which has developed a range of heritage sites and commemorative practices to secure its position in the musical landscape (Baker and Huber 2013, Martin 2011 ). The recent flourish of scholarly activity on a diverse array of heritage activity occurring in Australia reflects the increasing positioning of popular music as central to individual, 
community and national identity, and a recognition that the artefacts associated with its past are worth preserving. It also reflects the increasing utility of popular music history and heritage as an economic driver. Beyond the Australian context, this is seen most prominently in a city like Liverpool, UK, which has used its association with prominent musical figures to drive tourism and other cultural activities (see Cohen 2012, Brocken 2015, and also chapters 13 and 39 in this volume). In Australia similar activities can be observed in the regional town of Tamworth, the self-proclaimed Country Music Capital.

At the same time, the establishment of the Vault raises many questions about the processes by which decisions are made about what is included in an institution of this nature, and who gets to make those decisions. Definitions are an issue here; both 'popular music' and 'heritage' are highly contested terms, with no consensus even among scholars working in these areas. Defining popular music in different ways leads to the inclusion or exclusion of certain musical genres, eras, or geographic location (see Bruce Johnson, chapter 2 in this volume). Heritage is increasingly recognised as having many different aspects, as the recognition by UNESCO of the value of intangible heritage has demonstrated. In relation to popular music, Les Roberts and Sara Cohen's (2014) highly influential work in this area has led to distinctions being drawn between heritage that is authorised (official), self-authorised (determined by authoritative voices in the industry or community) and unauthorised (on a more everyday level, or even anti-heritage), which allows for considerable subtlety in the analysis of the construction of the past of an art form that has always had an important bottom-up component. However, even Roberts and Cohen note that drawing a line between what is heritage and what is not is very difficult, especially with a category like unauthorised heritage. The Australian Music Vault has not (as yet) released a statement giving clear insight into what they see as falling within their remit in relation to these issues.

That two of the Vault's named patrons, Molly Meldrum and Michael Gudinski, represent an already well-mythologised story of what is important in Australian music raises questions about how much space the Vault will give to histories that stand outside, or run counter to, the 'standard' version that has been presented in books, television shows and media. To what extent, for instance, will Indigenous Australians, or women, or musicians from outside Australia's urban centres, be included in the Vault? These types of questions relate, of course, to all histories, and the answers are always highly political, reflecting who is given authority to speak more broadly in a society. As popular music is a cultural form that has been 
important to people from all walks of life, and which has been recorded and archived as often by fans and musicians as by historians or museums, ensuring the incorporation of a variety of voices becomes doubly important. Much of the academic work on popular music history and heritage to date has engaged with the multitude of ways in which fans have acted as keepers of history (through exhibitions, DIY archives, websites, Facebook pages, artwork and so on), and museums have been working to try to incorporate fans' perspectives into exhibitions (see Leonard, chapter 27 in this volume). By all indications the Vault will do likewise, but how this plays out when the institution opens will depend on many factors, not least continued political good will and funding.

The surge in community- and government-driven preservation activities that have emerged globally, as exemplified by the Vault project, has been matched by a similarly exponential growth in the sub-field of popular music studies and critical heritage studies. The idea that popular music and its associated cultural trends could be considered an important aspect of history or heritage has required a paradigmatic shift in the thinking in the museal, curatorial and archival fields, and a reconsideration of who creates, writes, and preserves histories, and the meaning of heritage to everyday people. This has lead to increasing hybridity in the ways popular music history and heritage is dealt with by scholars all over the world.

The presence of the topic is evidenced in written work featured in devoted journals (Popular Music History) and to special issues in journals such as International Journal of Heritage Studies (Brandellero et al. 2014) and Popular Music and Society (Bennett and Janssen 2016). The proliferation of monographs, small edited collections, symposia and conferences, and even educational courses, further corroborates the growing viability of the field in its own right (for example, see Inglis 2006, Lipsitz 2007, Reynolds 2011, Baker 2015, Cohen et al. 2015, Pickering and Keightley 2015, Roy 2015, Bennett and Rogers 2016). The purpose of the current volume is to bring together the broadening range of popular music heritage applications in a digestible format, one that scholars new and experienced in the field can dip into for the foundational and progressive ideas captured here in the early twenty-first century.

Despite the breadth of research covered in this volume, there are still areas in need of greater attention. One such area is the intersection between class and popular music history or heritage. Certainly, the basis of many forms of popular music and related subcultures can be found in class struggles (e.g. punk, skiffle) or even class elitism (e.g. the hedonistic nature of 
1980s dance pop). The development of these genres over time obviously had impacts on the continued generation of new musics, but also new forms of heritage communities. Though the influence of class is evident in much research in music sociology and the adjacent domain of cultural studies, the area is yet to receive adequate scholarly attention.

Similarly, despite increasing attention given to the importance of archival practices for the preservation, mourning and celebration of queer histories (see Cvetkovich 2003, Halberstam 2005, Bly and Wooten 2012, Kumbier 2014), little scholarly literature has focused on queer heritage in relation to popular music specifically. Exceptions include Withers' $(2014,2015)$ work on The Women's Liberation Music Archive; Eichhorn's (2013) work on feminist collections focused on zines and Riot Grrrl; Reitsamer's (2015) work on physical and online feminist music archives in Europe; and recent work by Cantillon, Baker and Buttigieg (2017) that speaks to the relevance of sexuality in popular music archives. Such literature is significant to broader heritage discourses in that it highlights the affective and (potentially) activist nature of archives, which can challenge the mainstream historical narratives and musical canons that have traditionally marginalised queer figures and pasts. While there is no chapter devoted to sexuality in this volume, Reitsamer's analysis of popular music and gender in Chapter 3 incorporates a discussion of lesbian and queer music-making practices.

The volume is divided into five sections. The first three apply distinct lenses to our relationship with the past, demonstrating that different theoretical perspectives are needed, and different understandings of the past will be developed, depending on whether we take an approach that is about history, thinking about how history is constructed, heritage or memory. Section four explores the significance of specific institutions that have played important roles in retaining, exhibiting or redefining popular music's past. The final section presents a series of case studies that give an overview of the diversity of activity in this area, with an emphasis on incorporating voices from outside the Anglo-American sphere.

\section{Section 1: history and historiography}

History is often thought of as the record of the past. It is by its nature considered to be rigorous, and to at least some degree objective: a reporting of the things that happened and when they happened. Historiography, on the other hand, gives us some insight into the processes that create what constitutes history. In the case of popular music, the gap between its rise and it being taken seriously as a subject of academic inquiry meant that many key 
historical narratives about popular music were established first through media representations. The chapters in this section investigate the history of popular music and its construction, with an eye to understanding whose voices have been included, whose have been left out or marginalised, and what ideologies underpin the attribution of value to certain artists, scenes and genres.

The section opens with Bruce Johnson questioning fundamental assumptions about the subject matter at hand. In particular he challenges the often taken-for-granted lines that are drawn around what we think of as 'popular' music, arguing that there is a case to be made for the history of popular music being much longer, and wider, than we often understand it. There may be aspects of history - not only in terms of music - that we are denying ourselves access to by adhering to accepted definitions. The following two chapters pick up on this theme of challenging accepted histories by highlighting two areas where popular music histories have been lacking or contested. In Chapter 3, Rosa Reitsamer discusses how female musicians have been excluded and marginalised in popular music production and histories. She explores how, despite this under-representation in mainstream practices and discourses, feminist and queer online archivists are actively working to document and preserve women's music-making as heritage, and to offer alternative narratives of popular music's history. Nabeel Zuberi then turns our attention in Chapter 4 to the racial politics of popular music production, consumption, scholarship and heritage. Zuberi critiques how race has been dealt with in popular music histories (particularly in a US context), and considers the importance of phonographic and digital media technologies in transforming how we understand racialised history and heritage.

Bringing the importance of music to the foreground in Chapter 5, Richard Elliott examines the recent history of popular music - particularly in relation to sound recording and storytelling - through a musicological approach. In doing so, he identifies three key strands of musicological inquiry into popular music histories, differentiating between those that investigate scholarly concerns, phonography, and creative practice. He makes the important point that simply listening to music of the past may not be enough to engage with it, without an understanding of the context in which it was produced. Ways in which we can understand such contexts are the focus of Chapter 6, in which Steve Waksman considers the emergence of 'the historical turn' in popular music studies, focusing specifically on examples from the US. The chapter surveys some early historical accounts of popular music, as well as notable 
revisionist accounts that worked to reframe dominant understandings of the music industry and recording technologies, and to re-examine the significance of race and gender. These questions of who and what history focuses on are picked up again in Chapter 7, where Vaughn Schmutz discusses dynamics of cultural consecration and canon formation in popular music, examining how popular music has come to secure 'aesthetic legitimacy' (or symbolic value, as opposed to only economic value). Schmutz considers the various forces which shape the ever-shifting canon(s), from critical acclaim and peer recognition, to collectors and DIY archivists, to the influence of race, gender and transnational flows.

The chapters which close this first section of the volume analyse a number of different media that have been pivotal to the construction of popular music's history, to examine how each format has given specific forms to the stories told. In Chapter 8, Jon Dale addresses the practice of writing in historiography - that is, how popular music histories have been documented, by whom, from which perspectives, and in what forms. He speaks of the prominence of books (including monographs, edited collections, and [auto]biographies) in writing popular music history, but also emphasises the importance of diverse, unconventional publications like fanzines and blogs. Chapter 9 continues this emphasis on the written word, with Dave Laing and Catherine Strong analysing the significance of music magazines. Whether mainstream specialist publications, fanzines, or trade periodicals, music magazines offer valuable historical insights into the music industry through elements such as reviews, photographs, cartoons, interviews, advertisements, charts and polls. As such, these publications are important artefacts of popular music's past, and rich resources for the study of its history. Moving from the written word to screen, Chapter 10 offers an examination of how film and television have been used to document popular music history. Tim Wall and Nick Pillai focus on music documentaries, concert films and biopics, evaluating the representational nature of these genres, and how these genres come to take on particular structures that shape how a story can be told. However, the ability to actually include music in documentaries and television shows means unlike music writing, audio-visual histories become archives of the music as well as the stories told about it.

In the concluding chapter in this section, Antti-Ville Kärjä turns to the role of archives in popular music historiography. Chapter 11 addresses the distinctive characteristics of the music archive as a form of cultural and historical preservation, discussing the multimodality 
of its artefacts and the agendas and criterion (for example, 'cultural significance' and 'geographic region') which inform practices of acquisition.

\section{Section 2: heritage}

If history is a record of the past, heritage is those aspects of the past that are important in creating a sense of identity among a particular group of people, whether a nation, a city, or a neighbourhood. Heritage is, therefore, highly contested and always changing; this can be seen clearly in the way popular music has become incorporated into various heritage discourses over the last few decades. Paul Long opens the section with a discussion of the forces which influence our understandings of popular music as heritage. In Chapter 12, Long considers tangible and intangible forms of heritage, the relationship of heritage to history and memory, and movements toward the democratisation of cultural value in heritage practices, looking particularly at questions of the legitimacy of pop as heritage object. Henry Johnson then considers the interconnections between politics and popular music heritage production. In particular, Chapter 13 highlights how heritage is shaped by power relations and the top-down processes of governments, commercial organisations, and initiatives of exhibition and display, such as through the bestowal of awards or other honours to musicians. Leading on from this, to focus on another powerful force that shapes popular music heritage, Chapter 14 discusses the impacts of global flows on local culture. Robert Knifton draws on examples from around the world to consider the complex dynamics involved in processes of homogenisation, local participation and hybridisation, and how these play out in transnational and post-colonial contexts.

The section then moves to a series of chapters that highlight specific practices and uses of popular music heritage. In Chapter 15, Brett D. Lashua examines popular music tourism in this regard. He uses two case studies - 'Standin' on a Corner Park' in Winslow, Arizona and the Rock and Roll Hall of Fame in Cleveland, Ohio - to explore how authorised, selfauthorised and unauthorised forms of heritage are produced through tourism. Andy Bennett extends this discussion in Chapter 16, looking specifically at the history of DIY music practices and contemporary enactments of DIY preservationism. Bennett explains how fans (or 'prosumers') can help to salvage and preserve music at risk of being lost and forgotten, as he demonstrates through two examples: websites dedicated to the Canterbury Sound scene, and a record label specialising in reissues of heritage rock music. In the penultimate chapter of this section, Shane Homan examines tribute bands - particularly those paying homage to 
British bands from the 1960s - as heritage. Chapter 17 considers tribute bands' relations to the 'original' acts, and the legal, ethical, commercial and conceptual implications of their existence within contemporary music industries and historical discourses of popular music.

Whereas many chapters in this volume focus on the preservation of popular music heritage, the final chapter in this section by Catherine Strong considers the destruction of heritage. This destruction can manifest in various ways, with the examples in Chapter 18 focusing on the intentional destruction of artefacts for a political or artistic purpose, and destruction of famous music venues as a consequence of gentrification. The chapter emphasises the centrality of 'loss' to heritage discourses and preservationist impulses, and explores some of the common public responses to it - often involving grief, anger and contested claims over ownership and heritage value. However, Strong makes the point that destruction is necessary in order for any artefacts to have meaning, and can result in creativity and new forms of heritage.

\section{Section 3: memory}

In comparison to history, memory is often conceived of as being more ephemeral, and belonging more to the minds of individuals or the stories that are passed between them. However, the relationship between memory and history or heritage and the boundaries between them are far more complicated and difficult to define than is initially apparent. Popular music sits in a unique position as a mass produced commodity that is widely shared but nevertheless makes indelible impressions on the lives of individuals, and which holds a powerful position in terms of memory. Michael Pickering uses this understanding of music as his starting point in the opening chapter of this section. He goes on to explore the 'mnemonic imagination', noting the relations between individual and collective memory, past and present, and forgetting and remembering. In particular, Chapter 19 points to how these processes are mediated by technological changes and commercial initiatives (such as retrotyping). Pickering provides a broad framework for considering the functions music performs in individual, collective and nostalgic memory, and via different technologies, which the following chapters go on to address in more detail.

Lauren Istvandity begins this exploration with her chapter concentrating on personal, autobiographical memory. Chapter 20 provides an overview of the ways in which connections between music, memory and affect have been studied and conceptualised in 
psychology and the humanities, highlighting the significance of popular music to individuals' everyday experience and life course. Chapter 21 then shifts focus to mediated memory and collective memory, and how these interact. Examining (sub)cultures, places and events, Ben Green demonstrates the ways in which popular music comes to mediate memory, and vice versa, and how such processes are implicated in both personal and collective contexts. Delving further into mediated memory, Amanda Brandellero, Marc Verboord and Susanne Janssen's contribution looks at how musical memories are shaped by age, generation, place, locality and nationality. Drawing on surveys undertaken among different age cohorts in Netherlands and the UK, Chapter 22 explores the role of music in daily life and memories of one's youth, how its consumption has changed over time alongside advancements in technology, and how music preferences are influenced by one's country or region of origin.

The final three chapters in this section consider how music can be framed as an object to be remembered in particular ways, either collectively or individually, when placed in, or associated with, certain contexts or locations. In Chapter 23, Irene Stengs discusses commemorative ceremonies, monuments and acts of musical pilgrimage. She explores processes of myth formation surrounding famous musicians and musical events, as well as the importance of senses, affects, materiality and place in commemorative rituals, using acts of remembrance devoted to Dutch artist André Hazes as an example. Following this, Arno Van der Hoeven takes a sociological approach to understanding the role of nostalgia in popular music production and consumption. As he suggests in Chapter 24, nostalgic narratives are significant within the cultural industries and among audiences of popular music, functioning to shape senses of identity and belonging on both individual and collective levels. In the final contribution in this section, Jez Collins considers how musical memories are expressed and preserved in virtual environments, such as community-run, participatory archival websites and Facebook groups. Chapter 25 examines how digital technologies and online connectivity have fostered possibilities for communities of interest to digitise, upload, share and celebrate memories, generating their own self-authorised forms of popular music heritage.

\section{Section 4: institutions}

Institutions are central in supporting physical sites of heritage and history. Given the traditional approaches to storage, exhibition, and curation, often official institutions have been the most resistant, or at least the most challenged, in accepting and facilitating popular 
music as the focus of preservation processes. In the opening chapter of this section, Marion Leonard focuses on the increasing presence of popular music heritage in museums, institutions which significantly shape our understandings of the past and of what has heritage value (Chapter 26). She discusses the diversity of these institutions and their collection practices, the challenges associated with archiving and curating popular music, and the potentialities offered by digitisation.

The section progresses with a comprehensive history of the development and use of sound archives, which are here problematised by Noel Lobley for their role in both preserving and endangering the illicit use of sampled sound archive recordings (Chapter 27). This chapter outlines the modern day position of sound archives not merely as the stores of ethnomusicology data, but as working in sync with the commercial music industry, while also enabling cutting edge research and artist development. Alongside archives and museums, sites known as 'halls of fame' can present special considerations in their celebration of popular music history and heritage. In Chapter 28, Raphaël Nowak and Sarah Baker focus on popular music halls of fame in the USA, Australia and New Zealand. As heritage institutions, halls of fame are distinctive from dedicated museums or archives in that they involve processes of induction to determine which musicians and histories are preserved, celebrated and consecrated. The authors scrutinise the criteria by which musicians are inducted, as well as the ideals of popular music such institutions represent and reinforce. Withers' chapter (Chapter 29) explores community-led, do-it-yourself, do-it-together heritage institutions. Focusing on how such heritage projects manifest in digital contexts under neoliberalism, Withers examines DIY cultural practices in terms of (self-)authorisation and archival activism.

The section concludes with Elodie A. Roy's chapter (Chapter 30), which deals specifically with archival and reissue record labels. She identifies three waves in the development of such practices, from the first labels which typically emerged out of institutionalised sound archives, to the commercial reissuing initiatives impelled by major labels, to the proliferation of independent reissue record labels which have flourished with the rise of internet. Through the exploration of two case studies - the French archival record label Frémeaux \& Associés, and the British record label Finders Keepers - Roy highlights the significance of reissuing practices to the consumption of popular music and the ongoing production of its heritage. 


\section{Section 5: case studies}

The technological developments, corporate structures and specific musical styles that are most closely associated with 'popular music' developed in the global north, and the story (usually of a top-down nature) that is typically told about them is that they have since been disseminated to and adopted in other regions. The case studies in this section demonstrate how the outcome of this process, in terms of the creation of musical histories and heritage, is complicated and results in different results in different cultures. Rather than supplanting them, popular music interacts with local music-making practices, often resulting in new opportunities for 'traditional' music to be disseminated and documented. This is demonstrated clearly in the first chapters of this section. To begin, in Chapter 31 Åse Ottosson's concentrates on the popular music-making practices of Indigenous people in Central Australia. She highlights the diverse nature of these musics, which are shaped by intersecting local, national and global experiences, sounds, practices, ideas and genres. As an intercultural practice and process, Ottosson argues that Indigenous Australian popular music heritage must therefore be understood as Australian heritage more broadly, rather than being separated into its own category. In the following chapter, Dan Bendrups, Pip Laufiso and Hiliako Iaheto come to a similar conclusion as they delve further into popular music's intangible cultural heritage, focusing specifically on music from Pacific Island nations (Chapter 32). Using a song by a New Zealand-based reggae band as an example, the authors argue that popular music can be a means through which authentic expressions of Indigenous culture can be articulated.

In other regions, political attitudes - whether towards popular music itself or in regard to the social groups associated with certain types of music making - can shape the music that gets made and its likelihood of being incorporated into heritage discourses. In this vein, in Chapter 33 Jayson Beaster-Jones examines the characteristics and significance of the 'film song' genre to popular music culture in India. He considers the history of the symbiotic relationship between India's film and music industries, and the role that film songs have recently come to play in discourses of the cultural heritage of India, despite longstanding opposition to the genre on the part of governmental policy and state-controlled media. In chapter 34, Emília Barna considers the relatively marginal position (as compared to classical and folk music) of popular music in Hungarian cultural heritage discourses. Focusing on two current popular music heritage projects - Cseh Tamás Programme, a national initiative, and Budapest Rock Hall of Fame, a community-led museum - Barna explores their relations to the historicisation 
of Hungary's social and political past, particularly in relation to its socialist era. Similarly, Schalk van der Merwe's chapter (Chapter 35) examines developments in the music industries and in popular music studies in South Africa, particularly in relation to the Afrikaans language and culture. He considers the social, political and historical contexts - such as the apartheid and post-apartheid eras - which have shaped its formation, as well as the racial hierarchies, class relations and ideals of nationhood which underpin it. In Chapter 36, Graeme Counsel focuses on sound archives in Guinea, West Africa, such as the Radio Télévision Guinée (RTG). He traces some of the major historical and political influences in Guinea's music-making practices, particularly in relation to government cultural policy initiatives. Counsel highlights that archives like the RTG do not simply preserve sound recordings of the past, but also reflect the ideologies which shaped music's creation and dissemination.

The final two chapters take a somewhat different approach in their case studies, focusing more on failures in heritage processes. Molish Kanaaneh (Chapter 37) outlines the distinctive features, structures, genres and themes of Palestinian popular music. Once a source of great creativity and innovation, he argues there has been a decline in the productivity of Palestinian popular music in contemporary times, marking its transition from current, living practice to heritage product. Kanaaneh highlights a gap in the literature regarding this 'heritagising' phenomenon, and suggests some of recent changes to the social and political landscape which may have contributed to it. In Chapter 38, Mike Brocken considers Beatles- and Merseybeatrelated popular music heritage sites in Liverpool, England, but with an emphasis on sites that have been effectively left out of the tourist activities associated with the band. Detailing the historical significance of Percy Phillips' recording studio - which was the site of some of the earliest recordings by The Quarrymen, who later became the Beatles - Brocken considers how place is commodified for tourism, and how different sites become more or less integrated into a city's tourism narratives.

The 38 chapters which comprise this volume offer the reader an overview of the state of the field, and a starting point from which a deeper exploration of issues concerning popular music's history and heritage can commence, with each chapter accompanied by a list of references that can be used to facilitate further reading. Heritage activities such as the Australian Music Vault will continue to present new opportunities to understand the relationships between popular music, history and memory, and how these play out among 
fans, musicians, curators and policy makers. Returning to the Vault, its newly launched website makes the following declaration about the institution's purpose:

It's a place to explore your love of music, revisit some of the big music moments of your life, share those memories and discover the exciting new stories of today's Australian music scene. (Australian Music Vault 2017, original emphasis) The final point here - that the curators of the Vault see its role as being about what is happening in the present as much as what has happened in the past - speaks to why having a thorough understanding of the history of popular music, as well as of the way we construct and think about that history, is important. The present, and the future, are constituted by the past, and it creates the conditions in which we act. By including consideration of current music, however, the Vault appears to also be wanting to avoid valorising past music at the expense of the present, a problem that has been examined by writers such as Reynolds (2011). The study of popular music history and heritage is still in an emergent phase, but as the chapters compiled here attest, this is a rich body of scholarship which is set to grow exponentially in the near future, especially as more historical milestones pass for this still relatively young cultural form. Keeping in mind how the present and future feature in this scholarship, even if not always obviously, reminds us that popular music continues to grow, evolve, and present new opportunities for understanding. 


\section{References}

Australian Music Vault, 2017. What's the vault? [online]. Available from:

http://www.australianmusicvault.com.au [Accessed 1 November 2017].

Baker, S., ed., 2015. Preserving popular music heritage: do-it-yourself, do-it-together. New York: Routledge.

Baker, S. and Huber, A., 2013. Locating the canon in Tamworth: historical narratives, cultural memory and Australia's 'Country Music Capital'. Popular Music, 32 (2), 223-240.

Bennett, A. and Janssen, S., eds., 2016. Popular Music and Society, special issue on 'Popular music, cultural memory, and heritage', 39 (1).

Bennett, A. and Rogers, I., 2016. Popular music scenes and cultural memory. New York: Palgrave.

Bly, L. and Wooten, K., eds., 2012. Make your own history: documenting feminist and queer activism in the 21st century. Los Angeles: Litwin Books.

Brandellero, A., et al., eds., 2014. International Journal of Heritage Studies, special issue on 'Popular music heritage, cultural memory and cultural identity', 20 (3).

Breen, M., 2016. Melbourne popular music in the museum: locating the academy in the sonic city. Perfect Beat, 17 (2), 124-143.

Brocken, M., 2015. The 21st century legacy of the Beatles. Farnham: Ashgate

Cantillon, Z., Baker, S., and Buttigieg, B., 2017. Queering the community music archive. Australian Feminist Studies, 32 (91-92), 41-57.

Cohen, S., 2012. Musical memory, heritage and local identity: remembering the popular music past in a European capital of culture. International Journal of Cultural Policy, 19 (5), 576-594. 
Cohen, S., et al., eds., 2015. Sites of popular music heritage: memories, histories, places. New York: Routledge.

Creative Victoria, 2016. Australia music history - straight from the vault [online]. Available from: http://creative.vic.gov.au/news/2016/australia-music-history-straight-from-the-vault [Accessed 12 October 2017].

Cvetkovich, A., 2003. An archive of feelings. Durham: Duke University Press.

Dwyer, M., 2017. Melbourne's Music Vault to offer a peek inside the rock'n'roll wardrobe. The Age [online], 25 August. Available from:

http://www.smh.com.au/entertainment/melbournes-music-vault-to-offer-a-peek-inside-therocknroll-wardrobe-20170818-gxzp3v.html [Accessed 12 October 2017].

Eichhorn, K., 2013. The archival turn in feminism: outrage in order. Philadelphia: Temple University Press.

Halberstam, J., 2005. In a queer time and place: transgender bodies, subcultural lives. New York: New York University Press.

Homan, S., 2017. Australian popular music history on television: Long Way to the Top. History Australia, 14 (3), 429-443.

Inglis, I., ed., 2006. Performance and popular music: history, place and time. Farnham: Ashgate.

King, S.A., 2006. Memory, mythmaking, and museums: constructive authenticity and the primitive blues subject. Southern Communication Journal, 71 (3), 235-250.

Kumbier, A., 2014. Ephemeral material: queering the archive. Sacramento: Litwin Books.

Lipsitz, G., 2007. Footsteps in the dark: the hidden histories of popular music. Minnesota: University of Minnesota Press. 
Martin, T., 2011. Country Music Capital: the past in Tamworth. History Australia, 8 (1), 153-174.

Pickering, M. and Keightley, E., 2015. Photography, music and memory: pieces of the past in everyday life. New York: Palgrave Macmillan.

Reitsamer, R., 2015. Alternative histories and counter-memories: feminist music archives in Europe. In: S. Baker, ed. Preserving popular music heritage. New York: Routledge, 91-103.

Roy, E., 2015. Media, materiality and memory: grounding the groove. Farnham: Ashgate.

Roberts, L. and Cohen, S., 2014. Unauthorising popular music heritage: outline of a critical framework. International Journal of Heritage Studies, 20 (3), 241-261.

Reynolds, S., 2011. Retromania: pop culture's addiction to its own past. London: Faber and Faber.

Strong, C., 2015. Laneways of the dead: memorialising musicians in Melbourne. In: C. Strong and B. Lebrun, eds. Death and the rock star. Aldershot: Ashgate, 103-118.

Strong, C., Cannizzo, F., and Rogers, I., 2017. Aesthetic cosmopolitan, national and local popular music heritage in Melbourne's music laneways. International Journal of Heritage Studies, 23 (2), 83-96.

Withers, D., 2014. Re-enacting process: temporality, historicity and the Women's Liberation Music Archive. International Journal of Heritage Studies, 20 (7-8), 688-701.

Withers, D.M., 2015. Feminism, digital culture and the politics of transmission: theory, practice and cultural heritage. London: Rowman \& Littlefield International. 